\title{
INVENTORY CONTROL INDIRECT MATERIAL: EOQ MODEL, EFEKTIVITAS PRODUKSI
}

\author{
Afifi Bachtiar \\ Fakultas Ekonomi Universitas Prof. Dr. Hazairin, SH Bengkulu \\ afifibbach@yahoo.com
}

\begin{abstract}
ABSTRAK
Afifi Bachtiar: Penelitian ini bertujuan untuk mengetahui bagaimana Inventory Control Indirect Material berupa cup ukuran $240 \mathrm{ml}$ guna meningkatkan efektivitas produksi pada PT. Curup Aquifers. PT. Curup Aquifers selama ini menggunakan metode sederhana, sedangkan dengan menggunakan metode EOQ perusahaan menghasilkan biaya yang lebih murah jika dibandingkan dengan metode yang selama ini diterapkan oleh perusahaan. Penghematan yang dihasilkan jika metode EOQ jika diterapkan pada perusahaan pada tahun 2013 sebesar Rp 76.754.449.
\end{abstract}

\section{ABSTRACT}

Afifi Bachtiar: Purpose of this research to know how Inventory Control Indirect Material in the form of cup size $240 \mathrm{ml}$ in order to increase production effectivity at PT. Curup Aquifers. PT. Curup Aquifers has been using simple methods, while using the company's EOQ method produces cheaper cost when compared with the method that has been applied by the company. The savings generated if the EOQ method if applied to the company in 2013 amounted to $R p$ 76,754,449.

Keywords:: Indirect Material : EOQ Model, Efektivitas Produksi

\section{LATAR BELAKANG}

Krisis ekonomi berkepanjangan mengakibatkan persaingan antar perusahaan menjadi semakin ketat. Perusahaan yang mampu menekan biaya produksi seminimal mungkin dengan tanpa mengurangi kualitas produk yang dapat bertahan. Salah satu cara menekan biaya produksi dengan menekan total biaya persediaan bahan baku yang seminimum mungkin, baik dalam biaya pesanan, penyimpanan, kehilangan, dan perusakan bahan baku. Persediaan bahan baku harus dapat memenuhi kebutuhan rencana produksi, karena jika persediaan bahan baku tidak dapat dipenuhi, akan menghambat proses produksi.

Keterlambatan jadwal pemenuhan produk yang dipesan konsumen dapat merugikan perusahaan dalam hal image yang kurang baik. Sedangkan jika persediaaan bahan baku berlebihan dapat meningkatkan biaya penyimpanan, kerusakan, dan kehilangan bahan baku.

Air merupakan bahan baku yang sangat penting bagi kehidupan manusia dan fungsinya bagi kehidupan tidak pernah dapat digantikan oleh senyawa lain. Air minum adalah air yang melalui proses pengolahan atau tanpa proses pengolahan yang memenuhi syarat kesehatan dan dapat langsung diminum.

Dalam Peraturan Menteri Kesehatan Republik Indonesia Nomor : 907/MENKES/SK/VII Tahun 2002 , tentang syarat-syarat dan pengawasan kualitas air. Saat ini masyarakat mulai sadar akan kebutuhan air minum yang mempunyai kualitas baik. Terpenuhinya kebutuhan air minum dengan kualitas yang baik, memungkinkan masyarakat hidup secara, sehat. Sebagian besar kebutuhan air minum tersebut selama ini dipenuhi dari sumber air sumur atau dari permukaan yang telah diolah.

Saat ini air PDAM belum memenuhi standar air minum yang sehat dan bisa langsung diminum, melainkan harus dimasak dahulu untuk membunuh bakteri yang kemungkinan tidak mati oleh zat kimia (kaporit), oleh karena itu, pemakaian Air Minum Dalam Kemasan (AMDK) dewasa ini meningkat tajam.

Bisnis AMDK yang dibuat produsen minuman, selain bertujuan untuk memenuhi kebutuhan masyarakat, merupakan suatu bisnis yang dianggap menguntungkan. Hal ini disebabkan karena kebutuhan air minum semakin meningkat seiring dengan pertumbuhan penduduk. Faktor yang menyebabkan omset penjualan dan volume produksi dan volume produksi tumbuh, yaitu perubahan kesadaran masyarakat dalam mengkonsumsi air yang bersih. Berdasarkan keputusan Menperindag No. 167/1997, AMDK memiliki definisi yang jelas, yaitu yang telah diolah dan dikemas serta aman utuk diminum. Air minum dalam kemasan yang aman, harus memenuhi persyaratan air minum dalam kemasan yang diatur sesuai dengan Standar Nasional Indonesia (SNI) Nomor SNI-01-3553-1996. Untuk hal tersebut diperlukan pengendalian mutu dari awal sampai dengan akhir meliputi, bahan baku, proses produksinya, serta produk jadi, dalam hal ini yaitu produk AMDK. 
Menurut Mulyadi (1986 : 118) bahan baku adalah bahan yang membentuk bagian integral produk jadi. Bahan baku yang diolah dalam perusahaan manufaktur dapat diperoleh dari pembelian lokal, pembelian import atau dari pengolahan sendiri.

Adapun jenis-jenis bahan baku menurut Adisaputro dan Asri (1982 185) terdiri dari (1) Bahan baku langsung (direct material) adalah sennua bahan baku yang merupakan bagian dari pada barang jadi yang dihasilkan. Biaya yang dikeluarkan untuk membeli bahan mentah langsung ini mempunyai hubungan yang erat dan sebanding dengan jumlah, barang jadi yang dihasilkan. (2) Bahan baku tak langsung (indirect material) adalah bahan baku yang ikut berperanan dalam proses produksi, tetapi tidak secara langsung tamapak pada barang yang dihasilkan. Seandainya barang jadi yang barang yang dihasilkan adalah AMDK maka air merupakan bahan baku langsung, sedangkan botol palstik dan stiker merupakan bahan mentah tak langsung.

Kegiatan perusahaan mempunyai hubungan yang sangat erat dengan kegiatan produksi. PT. Curup Aquifers mengadakan kegiatan produksi untuk rnernenuhi kebutuhan pasar. Untuk mengadakan kegiatan produksi harus ada bahan baku. Oleh karena itu di dalam dunia usaha masalah bahan baku adalah masalah yang sangat penting. Sehingga diperlukan pengendalian persediaan bahan baku yang efektif dan efisien. Pengendalian persediaan bahan baku merupakan salah satu aspek yang sangat penting bagi berlangsungnya kelancaran suatu produksi. Hal ini berlaku untuk semua industry terutama industri yang bergerak dalam bidang AMDK.

PT. Curup Aquifers merupakan salah satu produsen Air Minum Dalam Kemasan (AMDK), dimana produknya adalah air dalam kemasan $240 \mathrm{ml}$, serta memiliki sumber bahan baku air yang berasal dari air pegunungan. Untuk mempertahankan kepuasan pelanggan, PT. Curup Aquifers secara terus menerus mengadakan pengendalian persedian bahan baku baik bahan baku langsung maupun bahan baku tidak langsung didalam produksinya, serta harus menjamin bahwa proses-proses tersebut dilakukan dibawah kondisi terkendali.

Pengendalian persediaan bahan baku tidak langsung pada produk PT. Curup Aquifers merupakan salah satu sistem yang dapat menjamin kelancaran proses produksi dengan lancar. Pengendalian tersebut dapat mencegah terjadinya kekurangan bahan baku yang dapat mengakibatkan terhambatnya proses produksi atau dapat menghentikan kegiatan produksi yang menyebabkan perusahaan menderita kerugian.

Persedian bahan baku tidak langsung PT. Curup Aquifers belum memenuhi kriteria pengelolaan persediaan yang baik. Sebab selama ini perusahaan dalam memesan bahan baku hanya berdasarkan perkiraan saja. Oleh karena itu diperlukan suatu metode dalam pengendalian persediaan bahan baku pada perusahaan tersebut, agar jumlah persediaan bahan baku disini optimal dan menurunkan biaya pemesanan.

\section{LANDASAN TEORI \\ Manajemen Operasi}

Manajemen Operasi merupakan salah satu fungsi perusahaan yang akan digunakan untuk mengendalikan aktivitas-aktivitas operasi didalam suatu perusahaan untuk mencapai tujuan-tujuan umum maupun khusus yang telah ditetapkan.

Haizer dan Render (2001:2) “Manajemen Operasional adalah serangkaian kegiatan yang membuat barang dan jasa melalui perubahan dari masukan menjadi keluaran."

Adapun menurut Tampubolon (2004:13): "Manajemen Operasi adalah sebagai manajemen proses konversi dengan bantuan fasilitas seperti tanah, tenaga kerja, modal dan manajemen masukan (inputs) yang diubah menjadi keluaran yang diinginkan berupa barang atau jasa atau layanan".

Dari definisi diatas dapat disimpulkan bahwa manajemen operasi merupakan suatu proses perubahan, pengaturan dan pengkoordinasian input-input atau sumber daya menjadi output yang berupa barang atu jasa secara efektif dan efisien sehingga mempunyai nilai tambah. Dalam proses perubahan tersebut dibutuhkan fasilitas- fasilitas penunjang seperti tanah dan bangunan, tenaga kerja, modal serta sumber-sumber pengadaan fasilitas lainnya.

\section{Pengendalian Persediaan}

Pengendalian persediaan (Inventory Control) adalah penentuan suatu kebijakan pemesanan dalam antrian, kapan bahan itu dipesan dan berapa banyak yang dipesan secara optimal untuk dapat memenuhi permintaan, atau dengan kata lain, pengendalian persediaan adalah suatu usaha atau kegiatan untuk menentukan tingkat optimal dengan biaya persediaan yang minimum sehingga perusahaan dapat berjalan lancar.

Menurut Assauri (2004:176) mengungkapkan bahwa "Pengendalian Persediaan adalah sebagai suatu kegiatan untuk menentukan tingkat dan komposisi dari persediaan parts, bahan baku dan barang 
hasil atau prodak, sehingga perusahaan dapat melindungi kelancaran produksi dan penjualan serta kebutuhan-kebutuhan pembelanjaan perusahaan dengan efektif dan efisien"

Rangkuti (2007:2) menyatakan bahwa persediaan adalah bahan-bahan, bagian yang disediakan, dan bahan-bahan dalam proses yang terdapat dalam perusahaan untuk proses produksi, serta barangbarang jadi atau produk yang disediakan untuk memenuhi permintaan dari konsumen atau pelanggan setiap waktu.

Dari definisi diatas dapat disimpulkan bahwa pengendalian persediaan adalah kegiatan untuk memelihara dan mengendalikan, juga suatu teknik pemesanan dan pemantauan barang-barang dalam kuantitas, jumlah dan waktu sesuai dengan yang direncanakan.

Menurut Siagian (2007:169), “Manajemen persediaan secara umum mengembangkan dua filosofi dasar, yaitu pendekatan sistem tarik (pull system) dan pendekatan sistem dorong (push system) yang memiliki pendekatan berbeda". Pendekatan sistem tarik (pull system)" prinsip pada sistem ini sangat cocok dilakukan pada perusahaan yang melakukan sistem Just In Time. Sistem tarik adalah suatu sistem yang memproduksi satu unit lalu ditarik ke tempat yang memerlukannya pada saat diperlukan. Sedangkan sistem dorong (push system), pada sistem ini pesanan ditumpuk di departemen pemerosesan agar dapat dikerjakan pada saat ada kesempatan.

\section{Penyebab Persediaan}

Persediaan merupakan suatu hal yang tak terhindarkan. Menurut Baroto (2002:53) mengatakan bahwa penyebab timbulnya persediaan adalah sebagai berikut:

1. Mekanisme pemenuhan atas permintaan

Permintaan terhadap suatu barang tidak dapat dipenuhi seketika bila barang tersebut tidak tersedia sebelummya. Untuk menyiapkan barang ini diperlukan waktu untuk pembuatan dan pengiriman, maka adanya persediaan merupakan hal yang sulit dihindarkan.

2. Keinginan untuk meredam ketidak pastian

Ketidak pastian terjadi akibat: permintaan yang bervariasi dan tidak pasti dalam jumlah maupun waktu kedatangan, waktu pembuatan yang cenderung tidak konstan antara satu produk dengan produk berikutnya, waktu tenggang (lead time) yang cenderung tidak pasti karena banyak faktor yang tidak dapat dikendalikan. Ketidak pastian ini dapat diredam dengan mengadakan persediaan.

3. Keinginan melakukan spekulasi yang bertujuan mendapatkan keuntungan besar dari kenaikan harga di masa mendatang.

\section{Jenis dan Fungsi Persediaan}

Setup jenis persediaan memiliki karakteristik tersendiri dan cara pengelolaan yang berbeda.

Rangkuti (2007:15) memaparkan persediaan dapat dibedakan menjadi beberapa jenis:

1. Persediaan bahan mentah (raw material) yaitu persediaan barang-barang berwujud, seperti besi, kayu, serta komponen-komponen lain yang digunakan dalam proses produksi.

2. Persediaan komponen-komponen rakitan (purchased parts/components), yaitu persediaan barangbarang yang terdiri dari komponen-komponen yang diperoleh dari perusahaan lain yang secara langsung dapat dirakit menjadi suatu produk.

3. Persediaan bahan pembantu atau penolong (supplies), yaitu persediaan barang-barang yang diperlukan dalam proses produksi, tetapi bukan merupakan bagian atau komponen barang jadi.

4. Persediaan barang dalam proses (work in process), yaitu persediaan barang-barang yang merupakan keluaran dari tiap-tiap bagian dalam proses produksi atau yang telah diolah menjadi suatu bentuk, tetapi masih perlu diproses lebih lanjut menjadi barang jadi.

5. Persediaaan barang jadi (finished goods), yaitu persediaan barang-barang yang telah selesai diproses atau diolah dalam pabrik dan siap dijual atau dikirim kepada pelanggan.

\section{Pengertian dan Jenis Bahan Baku}

Menurut Mulyadi (1986: 118) bahan baku adalah bahan yang membentuk bagian integral produk jadi. Bahan baku yang diolah dalam perusahaan manufaktur dapat diperoleh dari pembelian lokal, pembelian import atau dari pengolahan sendiri.

Adapun jenis jenis bahan baku menurut Adisaputro dan Asri (1982: 185) terdiri dari :

1. Bahan Baku Langsung (Direct Material)

Bahan baku langsung adalah semua bahan baku yang merupakan bagian dari pada barang jadi yang dihasilkan. Biaya yang dikeluarkan untuk membeli bahan mentah langsung ini mempunyai hubungan yang erat dan sebanding dengan jumlah barang jadi yang dihasilkan.

2. Bahan baku tak langsung (Indirect Material) 
Bahan baku tak langsung adalah bahan baku yang ikut berperanan dalam proses produksi, tetapi tidak secara langsung tampak pada barang jadi yang dihasilkan. Seandainya barang jadi yang dihasilkan adalah meja dan kursi maka kayu merupakan bahan baku langsung, sedangkan paku dan plamir merupakan bahan mentah tak langsung.

\section{Komponen Biaya Persediaan}

Salah satu tujuan persediaan adalah mendapatkan biaya yang minimum. Oleh karena itu, menurut Nasution dan Prasetyawan (2008:121) dalam menentukan biaya persediaaan perlu diketahui bahwa biayabiaya yang mencakup dalam persediaan sebagai berikut:

1. Biaya penyimpanan (holding costs atau carrying costs), yaitu terdiri atas biaya-biaya yang bervariasi secara langsung dengan kuantitas persediaan.

2. Biaya pemesanan atau pembelian (ordering costs atau procurement costs).

3. Biaya kehabisan atau kekurangan bahan (shortage costs)

Schroeder (1993:584) mengemukakan jenis biaya sebagai berikut:

1. Item Cost, yaitu biaya yang dikeluarkan untuk membeli atau memproduksi item itu sendiri,

2. Ordering Cost, yaitu biaya pemesanan yang tedadi sehubungan dengan adanya kegiatan pemesanan. Mulai dari pemesanan bahan sampai pemeriksaan di gudang. Diantaranya biaya pemesanan pembelian, biaya bongkar muat, biaya transportasi, biaya pemeriksaan,

3. Carrying Cost, yaitu biaya yang timbul karena penyimpanan barang persediaan untuk periode waktu tertentu. Biaya penyimpanan ini biasanya dinyatakan dalam presentase nilai rupiah untuk per unit waktu.

\section{Model Pengendalian Persediaan.}

\section{Kuantitas Pesanan Ekonomis (Economic Order Quantity = EOQ)}

Menurut Subagyo (2000:134) "EOQ adalah jumlah pemesanan yang paling ekonomis. Yaitu jumlah pembelian barang, misal bahan baku atau pembantu, yang dapat meminimumkan jumlah biaya pemeliharaan barang digudang dan biaya pemesanan setiap tahun". EOQ menunjukkan jumlah barang yang harus dipesan untuk setiap kali pemesanan agar biaya sediaan keseluruhan menjadi sekecil mungkin.

Menurut Heizer dan Render (2005 :72), model kuantitas pesanan ekonomis (economic order quantity-EOQ) adalah salah satu teknik kontrol persediaan yang tertua dan paling dikenal, tetapi berdasarkan beberapa asumsi:

1. Jumlah pennintaan diketahui, konstan dan independen.

2. Waktu tunggu yakni waktu antara pemesanan dan penerimaan pesanan diketahui dan konstan.

3. Penerimaan persediaan bersifat instan dan selesai seluruhnya. Dengan kata lain, persediaan dari sebuah pesanan datang dalam satu kelompok pada suatu waktu.

4. Tidak tersedia diskon kuantitas.

5. Biaya variable hanya biaya untuk menyiapkan atau melakukan pemesanan dan biaya menyimpan persediaan dalam waktu tertentu.

6. Kehabisan persediaan dapat sepenuhnya dihindari jika pemesanan dilakukan pada waktu yang tepat.

Dengan asumsi tersebut, grafik penggunaa persediaan terhadap waktu memiliki bentuk gigi gergaji, seperti pada Gambar I. Permintaan bersifat konstan sepanjang waktu, persediaan menurun pada laju yang sama sepanjang waktu. Setiap kali tingkat persediaan mencapai 0, pesanan barn dibuat serta diterima, dan tingkat persediaan melompat ke EOQ. Proses ini terns berlanjut sepanjang waktu.

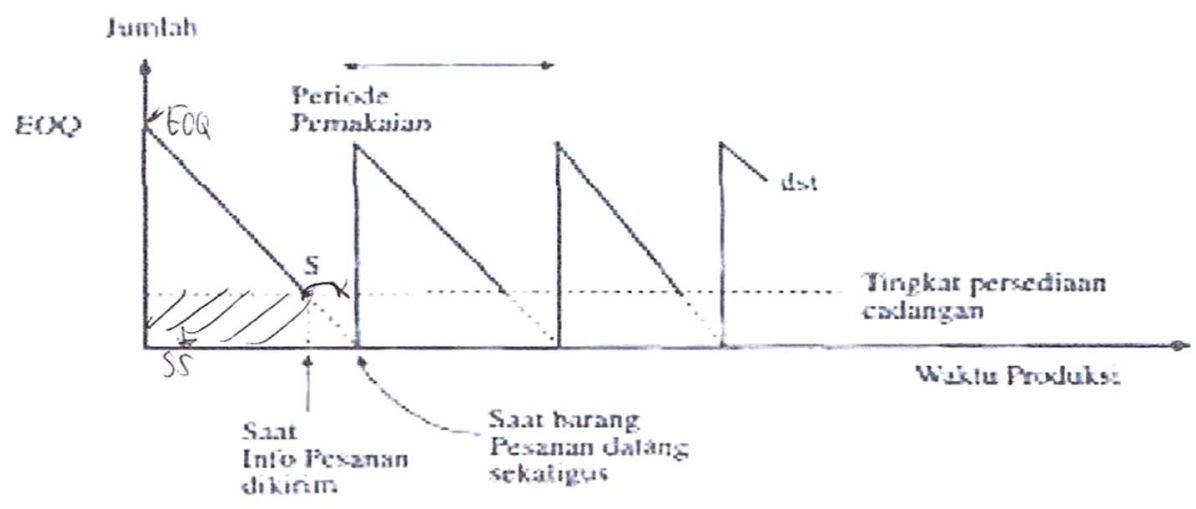

Gambar 1. Penggunaan Persediaan Dalam Waktu Tertentu

Sumber : Heizer dan Render (2005:72) 
$\mathrm{EQQ}=\sqrt{\frac{2 D S}{H}}$

Keterangan :

$\mathrm{S} \quad=$ Biaya setiap kali pesan

$\mathrm{D}=$ Jumlah kebutuhan bahan baku dalam satu periode

$\mathrm{H}=$ Biaya penyimpanan dinyatakan dalam presentase dari persediaan rata-rata

Pada Gambar II dibawah menunjukkan hubungan antara kedua biaya tersebut, biaya penyimpanan (holding/carrying cost) dan biaya pemesanan (ordering cost) dalam bentuk grafik. Kurva biaya penyimpanan menunjukkan sebuah garis lurus yang naik apabila jumlah persediaan bertambah besar.

Kurva biaya pesanan menunjukkan garis lengkung menurun mendekati nol apabila jumlah persediaan bertambah. Kurva biaya persediaan total (TC) merupakan penjumlahan dua kurva biaya tersebut, dimana kurva tersebut akan menurun dan mencapai titik minimum pada jumlah persediaan tertentu dan kemudian naik lagi. Dalam hal ini Q = EOQ akan tercapai pada perpotongan antara kedua kurva tersebut.

\section{Biaya}

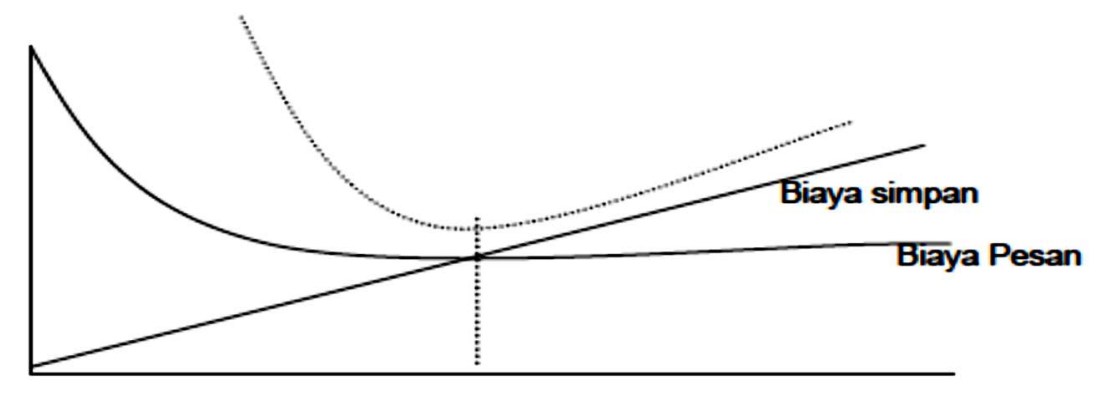

Jumlah Pemesanan

Gambar 2. Biaya total sebagai fungsi dari kuantitas pesanan Sumber : Heizer dan Render (2005)

\section{Persediaan Pengaman (Safety Stock)}

Menurut Pujawan (2005:104), safety stock fungsinya adalah sebagai perlindungan terhadap ketidakpastian permintaan maupun pasokan. Perusahaan biasanya menyimpan lebih banyak dari yang diperkirakan dibutuhkan selama suatu periode tertentu supaya kebutuhan yang lebih banyak bisa dipenuhi tanpa harus menunggu. Menentukan berapa besarnya persediaan pengaman adalah pekedaan yang sulit. Besar kecilnya persediaan pengaman terkait dengan biaya persediaan dan service level.

Menurut Ristono (2009:4), faktor-faktor yang menentukan besarnya safety stock adalah :

1. Penggunaan bahan baku rata-rata. Salah satu dasar untuk memperkirakan penggunaan bahan baku selama periode tertentu, khususnya selama periode pemesanan adalah rata-rata penggunaan bahan baku pada masa sebelumnya. Hal ini perlu diperhatikan karena peramalan permintaan langganan memiliki risiko yang tidak dapat dihindarkan bahwa persediaan yang telah ditetapkan sebelumnya atas dasar taksiran tersebut habil sama sekali sebelum penggantian bahan/barang dari pesanan datang.

2. Faktor waktu atau lead time (procurement time) Lead time adalah lamanya waktu antara mulai dilakukannya pemesanan bahan-bahan sampai dengan kedatangan bahan-bahan yang dipesan tersebut dan diterima di gudang persediaan. Lamanya waktu tersebut tidaklah sama antara satu pesanan dengan pesanan yang lain, tetapi bervariasi.

$$
\begin{array}{ll}
\qquad \mathrm{SD}=\frac{\sqrt{\sum(X-X)^{2}}}{n} \\
\mathrm{SD} & =\text { Standar Deviasi } \\
\mathrm{X} & =\text { Perkiraan kebutuhan } \\
\mathrm{X} & =\text { Rata-rata kebutuhan } \\
\mathrm{n} & =\text { Jumlah data }
\end{array}
$$




\section{Reorder Point (ROP)}

Menurut Riyanto (2001:69), reorder point ialah saat atau titik di mana harus diadakan pesanan lagi sedemikian rupa sehingga kedatangan atau penerimaan material yang dipesan itu adalah tepat pada waktu dimana persediaan di atas safety stock sama dengan nol. Dengan demikian diharapkan datangnya material yang dipesan itu tidak akan melewati waktu sehingga akan melanggar safety stock. Apabila pesanan dilakukan sesudah melewati reorder point tersebut, maka material yang dipesan akan diterima setelah perusahaan terpaksa mengambil material dari safety stock. Dalam penetapan reorder point haruslah kits memperhatikan faktor-faktor sebagai berikut yaitu, penggunaan material selama tenggang waktu mendapatkan barang (procurement lead time) dan besarya safety stock.

Reorder point dapat ditetapkan dengan berbagai cara, antara lain :

1. Menetapkan jumlah penggunaan selama lead time dan ditambah dengan presentase tertentu.

2. Menetapkan jumlah penggunaan selama lead time dan ditambah dengan penggunaan selama periode tertentu sebagai safety stock.

Menurut Heizer dan Render (2010:99) Titik pemesanan ulang (reorder point) dicari dengan cara : ROP $=($ Permintaan per hari) (lead time untuk pemesanan barn dalam hari)

$\mathrm{ROP}=\mathrm{d} \times \mathrm{L}$

(lead time* penggunaan Rata-rata) + safety stock

Persamaan untuk ROP ini mengasumsikan bahwa permintaannya sama dan bersifat konstan. Bila tidak demikian halnya, harus ditambahkan stok tambahan, seringkali disebut pengaman (safety stock).

\section{Pengertian Efektivitas}

Pengertian efektivitas menurut Sedarmayanti (2009: 59). Bahwa : “Efektivitas merupakan suatu ukuran yang memberikan gambaran seberapa jauh target dapat dicapai. Pengertian efektivitas ini lebih berorientasi kepada keluaran sedangkan masalah penggunaan masukan kurang menjadi perhatian utama. Apabila efisiensi dikaitkan dengan efektivitas maka walaupun tedadi peningkatan efektivitas belum tentu efisiensi meningkat"

Sedangkan menurut Yamit, (2003:14). efektivitas merupakan suatu ukuran yang memberikan gambaran seberapa jauh tujuan tercapai, baik secara kualitas maupun waktu, orientasinya pada keluaran yang dihasilkan".

Berdasarkan beberapa pengertian tersebut, dapat dijelaskan bahwa efektivitas seringkali berarti kuantitas atau kualitas (keluaran) dari barang dan jasa. Efektivitas adalah ciri yang baik dalam suatu organisasi, dapat dilihat dari tingkat keberhasilan organisasi yang relatif seperti tercapainya suatu tujuanorganisasi. Kegiatan yang dinilai efektif apabila output yang dihasilkan dapat memenuhi tujuan yang diharapkan.

\section{METODOLOGI}

\section{Populasi dan Sampel dan Teknik Pengambilan Sampel.}

Populasi dalam penelitian ini adalah seluruh data pembelian dan persedian bahan baku tak langsung yaitu berupa cup ukuran $240 \mathrm{ml}$. Sampel yang diambil dari populasi harus betul-betul representatif (mewakili). Penelitian ini mengambil sampel pembelian dan persedian bahan baku tak langsung yaitu berupa cup ukuran $240 \mathrm{ml}$ pada tahun 2013. Teknik pengambilan sampel dalam penelitian ini menggunakan teknik Purposive Sampling. Untuk mendapatkan kelengkapan informasi yang sesuai dengan fokus penelitian maka yang dijadikan teknik pengumpulan data adalah teknik wawancara (interview). observasi (pengamatan). dokumentasi.

\section{Metode Analisis.}

Teknik pembahasan yang digunakan dalam penulisan ini menurut Heizer dan Render (2005:72) :

1. Metode Economic Order Quantity (EOQ). Metode ini digunakan untuk mengetahui jumlah pembelian bahan baku yang dapat mencapai biaya persediaan yang paling minimal. EOQ adalah jumlah kuantitas barang yang diperoleh dengan biaya yang minimal atau pembelian paling ekonomis.

$$
\begin{aligned}
& \mathrm{EQQ}=\sqrt{\frac{2 D S}{H}} \\
& \text { Keterangan : } \\
& \mathrm{S}=\text { Biaya setiap kali pesan } \\
& \mathrm{D}=\text { Jumlah kebutuhan bahan baku dalam satu periode } \\
& \mathrm{H}=\text { Biaya penyimpanan dinyatakan dalam presentase dari persediaan } \\
& \quad \text { rata-rata }
\end{aligned}
$$

2. Total biaya persediaan bahan baku (TC)

Biaya total adalah seluruh biaya yang dikeluarkan untuk menghasilkan suatu produk. 
3. Menentukan persediaan penyelamat atau Safety Stock

$$
T C=\frac{D}{Q} s+\frac{Q}{2} H
$$

$$
\begin{array}{ll}
\mathrm{SD} & =\text { Standar Deviasi } \\
\mathrm{X} & =\text { Perkiraan kebutuhan } \\
\mathrm{X} & =\text { Rata-rata kebutuhan } \\
\mathrm{n} & =\text { Jumlah data }
\end{array}
$$

4. Titik pemesanan kembali atau reorder point (ROP)

ROP adalah suatu titik dimana harus dilakukan pemesanan pembelian kembali. ROP $=($ Lead Time* Penggunaan Rata-rata $)+$ safety stock

\section{HASIL PENELITIAN DAN PEMBAHASAN}

\section{Analisis Pengendalian Persediaan Bahan Baku Dengan Menggunakan Metode EOQ}

Perhitungan analisis pengendalian persediaan bahan baku dapat digunakan dengan metode EOQ. Hal ini dapat dilakukan karena kondisi, karakteristik, serta kebutuhan perusahaan memenuhi semua asumsi dalam metode EOQ. Perusahaan memiliki data permintaan yang diketahui tetap dan bebas, selain itu lead time konstan, penerimaan persediaan bersifat seketika dan lengkap, tidak ada diskon karena kuantitas tidak memungkinkan, biaya variabel yang ada hanyalah biaya pemesanan dan biaya penyimpanan, serta kosongnya persediaan dapat dihindari sepenuhnya jika pemesanan dilakukan pada waktu yang tepat.

Metode EOQ memungkinkan perusahaan untuk menentukan jumlah kuantitas pesanan bahan baku yang paling ekonomis dengan jumlah permintaan dan lead time yang konstan. Perhitungan kuantitas pemesanan optimal bahan baku cup $240 \mathrm{ml}$ optimal tahun 2013 secara terinci disajikan pada Tabel 1. dibawah ini:

Tabel 1. Perhitungan Kuantitas Pemesanan Optimal Bahan Baku Cup 240 ml Tahun 2013

\begin{tabular}{|c|c|c|c|c|}
\hline Bahan Baku & $\begin{array}{c}\text { Permintaan } \\
(\mathrm{D})\end{array}$ & $\begin{array}{c}\text { Biaya Pesan } \\
(\mathrm{S})\end{array}$ & $\begin{array}{c}\text { Biaya Simpan } \\
(\mathrm{H})\end{array}$ & $\begin{array}{c}\text { EOQ } \\
\sqrt{2} \times \mathrm{D} \times \mathrm{S} / \mathrm{H}\end{array}$ \\
\hline Cup $240 \mathrm{ml}$ & 1.754 .700 & 1.840 .444 & 221 & 170.955 \\
\hline
\end{tabular}

Sumber : Data diolah, 2014

Berdasarkan hasil perhitungan EOQ pada Tabel IX tersebut, diketahui bahwa kuantitas pemesanan optimal bahan baku cup $240 \mathrm{ml}$ pada tahun 2013 adalah sebanyak 170.955 pcs setiap kali pemesanan. Setelah mengetahui kuantitas pemesanan optimal bahan baku cup $240 \mathrm{ml}$ setiap kali pesan, frekuensi pemesanan baru dapat dihitung.Perhitungan frekuensi pemesanan optimal bahan cup $240 \mathrm{ml}$ disajikan pada Tabel 2.

Tabel 2. Perhitungan Frekuensi Pemesanan Optimal Bahan Baku Cup 240 ml Tahun 2013

\begin{tabular}{|c|c|c|c|}
\hline Bahan Baku & $\begin{array}{c}\text { Permintaan } \\
\text { (a) }\end{array}$ & $\begin{array}{c}\text { EOQ } \\
\text { (b) }\end{array}$ & $\begin{array}{c}\text { Frekuensi (kali) } \\
(\mathrm{a} / \mathrm{b})\end{array}$ \\
\hline Cup $240 \mathrm{ml}$ & 1.754 .700 & 170.955 & 10 \\
\hline
\end{tabular}

Sumber : Data diolah, 2014

Frekuensi pemesanan bahan baku cup $240 \mathrm{ml}$ berdasarkan metode EOQ lebih banyak atau sering bila dibandingkan dengan frekuensi pemesanan yang telah dilakukan berdasarkan metode perusahaan. Frekuensi pemesanan bahan baku cup $240 \mathrm{ml}$ dengan metode perusahaan dilakukan 9 kali dalam setahun, sedangkan pemesanan dengan metode EOQ dilakukan sebanyak 10 kali dalam setahun. Semakin besar frekuensi pemesanan, semakin besar pula biaya yang harus dikeluarkan perusahaan untuk biaya pemesanan, namun biaya penyimpanan akan semakin kecil.

Namun, biaya pemesanan saja tidak cukup untuk dapat membandingkan dua metode persediaan untuk mencari metode persediaan yang paling efisien. Hal ini disebabkan karena masih ada satu komponen biaya lagi yang memengaruhi total biaya persediaan secara keseluruhan, yaitu biaya penyimpanan yang mana dipengaruhi oleh jumlah rata-rata persediaan di gudang.

Total biaya persediaan merupakan jumlah dari total biaya pemesanan dan total biaya penyimpanan. Perhitungan biaya persediaan bahan baku berdasarkan metode EOQ tahun 2013 secara terinci pada tabel dibawah ini, sedangkan total biaya persediaan berdasarkan metode EOQ disajikan pada Tabel 3. 
Tabel 3. Total Biaya Persediaan Bahan Baku Berdasarkan Metode Eoq Tahun 2013

\begin{tabular}{|c|c|c|c|c|}
\hline Bahan Baku & $\begin{array}{l}\text { Frekuensi } \\
\text { Permintaan } \\
\text { (kali) } \\
\text { a }\end{array}$ & $\begin{array}{l}\text { Kuantitas/ } \\
\text { pesanan } \\
(\mathrm{Pcs}) \\
(\mathrm{Q} / 2) \\
\text { b }\end{array}$ & $\begin{array}{c}\text { Biaya } \\
\text { Pesanan/pesan } \\
\text { (Rp) } \\
\text { (S) } \\
\text { C }\end{array}$ & $\begin{array}{c}\text { Biaya } \\
\text { Simpanan/Pcs/tahun } \\
(\mathrm{Rp}) \\
(\mathrm{H}) \\
\mathrm{d}\end{array}$ \\
\hline Cup $240 \mathrm{ml}$ & 10 & 170.955 & 1.840 .444 & 221 \\
\hline
\end{tabular}

\begin{tabular}{|c|c|c|c|}
\hline Bahan Baku & $\begin{array}{c}\text { Biaya Pesanan/tahun } \\
(\mathrm{Rp}) \\
\mathbf{e}=\mathbf{a} \mathbf{~ x ~} \mathbf{c}\end{array}$ & $\begin{array}{c}\text { Biaya Simpanan/tahun } \\
\mathbf{( R \mathbf { p } )} \\
\mathbf{f}=\mathbf{~ b ~ x ~ d ~}\end{array}$ & $\begin{array}{c}\text { Total Biaya Persedian } \\
\text { (Rp) } \\
\mathbf{e}+\mathbf{f}\end{array}$ \\
\hline Cup $240 \mathrm{ml}$ & 18.404 .440 & 37.781 .055 & 56.185 .495 \\
\hline
\end{tabular}

Sumber : Data diolah, 2014

Pengendalian persediaan dengan menggunakan metode EOQ menghasilkan total biaya sebesar Rp. 56.185.495, dengan rincian biaya pemesanan sebesar Rp. 18.404.440 dan biaya penyimpanan sebesar Rp. 37.781.055. Penyajian biaya persediaan bahan baku menggunakan metode EOQ dalam bentuk gambar disajikan pada Gambar 3.

Gambar 3. Biaya Persediaan Bahan Baku Menggunakan Metode EOQ

\section{Total Biaya}

56.185 .495

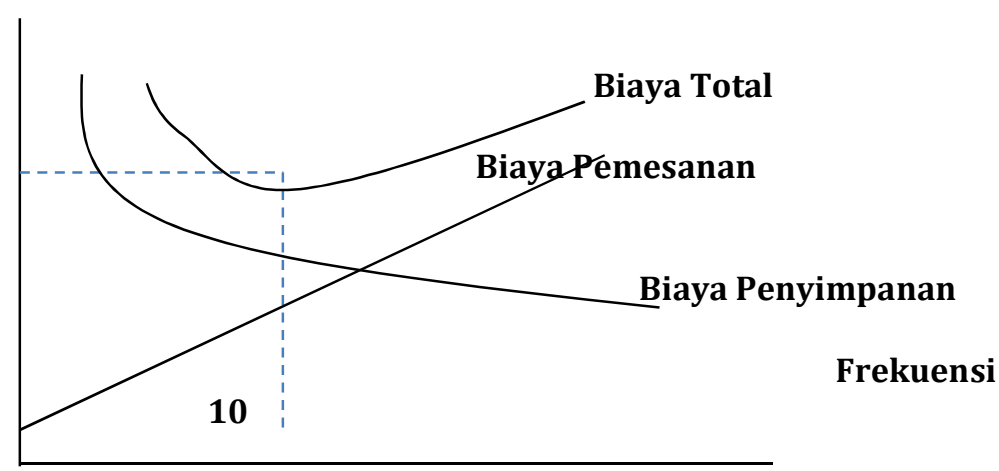

Ket : $\quad$ Biaya total $=$ Rp. 56.185.495

Biaya Pemesanan $=$ Rp. 1.840 .444

Biaya Penyimpanan $=$ Rp. 221

\section{Perbandingan Biaya Persediaan Bahan Baku}

Metode yang telah dilakukan oleh perusahaan secara aktual dapat dibandingkan dengan metode EOQ. Dengan mengetahui hasil perbandingannya, perusahaan akan mengetahui metode mana yang akan menghasilkan biaya paling minimum, yang berarti merupakan metode persediaan yang lebih efektif bagi perusahaan yang bila diterapkan akan menghasilkan keuntungan yang terbesar. Perbandingan tersebut disajikan pada Tabel 4 .

Tabel 4. Perbandingan Biaya Persediaan Bahan Baku Antara Kondisi Aktual Perusahaan Dengan Metode EOQ

\begin{tabular}{|c|c|c|}
\hline Uraian & $\begin{array}{c}\text { Bahan baku Cup } 240 \mathrm{ml} \\
\text { Rp/tahun }\end{array}$ & $\begin{array}{c}\text { Total } \\
\text { Rp/tahun } \\
\end{array}$ \\
\hline \multicolumn{3}{|l|}{ I. Aktual Perusahaan } \\
\hline 1. Biaya Pemesanan & 16.563 .996 & \\
\hline 2. Biaya Persedian & 116.375 .948 & \\
\hline 3. Biaya penyimpanan $(1+2)$ & 132.939 .944 & \\
\hline Total biaya persedian & & 132.939 .944 \\
\hline
\end{tabular}




\begin{tabular}{|c|c|c|}
\hline Uraian & $\begin{array}{c}\text { Bahan baku Cup } 240 \mathrm{ml} \\
\text { Rp/tahun }\end{array}$ & $\begin{array}{c}\text { Total } \\
\text { Rp/tahun }\end{array}$ \\
\hline \multicolumn{3}{|l|}{ II. Metode EOQ } \\
\hline 4. Biaya Pemesanan & 18.404 .440 & \\
\hline 5. Biaya Persedian & 37.781 .055 & \\
\hline 6.Biaya penyimpanan $(5+6)$ & 56.185 .495 & \\
\hline Total biaya persedian & & 56.185.495 \\
\hline \multicolumn{3}{|l|}{ III. Penghematan } \\
\hline 7. Biaya Pemesanan (1 - 4) & $(1.840 .444)$ & \\
\hline 8. Biaya Persedian (2 - 5) & 78.594 .893 & \\
\hline 9. Biaya penyimpanan $(3-6)$ & 76.754 .449 & \\
\hline Total Penghematan & & 76.754.449 \\
\hline
\end{tabular}

Sumber : Data diolah, 2014

Pada Tabel 4. ditunjukkan bahwa dengan menggunakan metode EOQ perusahaan dapat menghemat biaya sebesar Rp. 76.754 .449 per tahun. Pada kedua biaya bahan baku lainnnya yaitu biaya pemesanan dan biaya penyimpanan, biaya pemesanan dengan metode EOQ menghasilkan biaya pemesanan yang lebih besar yaitu Rp. 18.404.440, hal ini disebabkan oleh karena frekuensi pemesanan yang dilakukan untuk memesan cup $240 \mathrm{ml}$ dengan metode EOQ lebih sering dibandingkan dengan metode yang telah digunakan oleh perusahaan selama ini. Perusahaan menetapkan frekuensi pemesanan yang relatif sedikit, yaitu 9 kali selama satu tahun, sedangkan metode EOQ mengharuskan perusahaan melakukan pemesanan sebanyak 10 kali. Hal ini disebabkan oleh karena perusahaan tidak mau mengambil risiko kehabisan persediaan bahan baku dan ingin mempertahankan tingkat persediaan yang tinggi guna menjamin proses produksi dapat terus berlangsung. Dalam hal ini, risiko keusangan bahan baku tidak terlalu memengaruhi perusahaan oleh karena sifat bahan baku yang tidak mudah rusak atau relatif tahan lama, yaitu dengan umur simpan yang dapat mencapai satu tahun atau lebih bila bahan baku tetap terjaga dari gangguan seperti terkena air atau panas.

Dibandingkan dengan metode yang digunakan perusahaan, terlihat bahwa metode EOQ memberikan biaya persediaan Rp. 37.781.055 yang lebih rendah. Biaya penyimpanan dengan metode EOQ sebesar Rp. 56.185.495 lebih rendah dibanding dengan metode perusahaan. Kombinasi frekuensi dan jumlah bahan baku yang dipesan yang optimal menimbulkan biaya yang lebih sedikit, dalam arti lebih efisien. Perusahaan mampu menghemat dana yang dikeluarkan untuk biaya persediaan, sehingga kelebihan dana dapat digunakan atau diinvestasikan ke bagian lain yang membutuhkan yang pada akhirnya akan meningkatkan laba atau keuntungan bagi perusahaan.

\section{Titik Pemesanan Kembali (Reorder Point) dan Persediaan Pengaman (Safety Stock)}

Titik pemesanan kembali merupakan batas dari jumlah persediaan yang ada digudang saat pesanan harus diadakan kembali. Hal ini bertujuan agar perusahaan dapat mengetahui kapan waktu yang tepat untuk melakukan pemesanan. Titik pemesanan kembali atau yang dikenal dengan Reorder Point dapat ditentukan dengan cara menghitung rata-rata pemakaian bahan baku per hari selama waktu tunggu.

Perhitungan titik pemesanan kembali berdasarkan metode EOQ disajikan pada Tabel 5. Rata-rata pemakaian per hari ditentukan dengan cara membagi total kebutuhan per tahun dengan jumlah hari dalam setahun atau jumlah hari kerja per tahun. Pada penelitian ini diasumsikan bahwa hari kerja dan jumlah hari dalam setahunadalah sama yaitu 360 hari. Dengan demikian rata-rata pemakaian per hari adalah jumlah pemakaian per tahun yaitu 1.754 .700 pcs dibagi jumlah hari kerja dalam setahun (360 hari). Sedangkan untuk menentukan titik pemesanan kembali yaitu waktu tunggu selama 7 hari dibagi rata-rata pemakaian per hari sebesar $4.874 \mathrm{pc}$

Tabel 5. Perhitungan Titik Pemesanan Kembali (ROP) Berdasarkan Metode EOQ

\begin{tabular}{|c|c|c|c|}
\hline Bahan & $\begin{array}{c}\text { Waktu Tunggu } \\
\text { (hari) } \\
\mathbf{a}\end{array}$ & $\begin{array}{c}\text { Rata-rata } \\
\text { Pemakaian/hari (Pcs) } \\
\mathbf{b}\end{array}$ & $\begin{array}{c}\text { Titik Pemesanan } \\
\text { Kembali (Pcs) } \\
\mathbf{c}=\mathbf{a} \mathbf{~ x ~ b}\end{array}$ \\
\hline Cup $240 \mathrm{ml}$ & 7 & 4.874 & 34.119 \\
\hline
\end{tabular}

Ket : Rata-rata pemakaian/hari $=1.754 .700 / 360$ hari 
Sesuai dengan Tabel 5, perusahaan harus segera melakukan pemesanan pada saat persediaan di gudang sudah mencapai tingkat 34.119 pcs. Hal ini berarti bahwa pada saat persediaan bahan baku benar-benar habis, pesanan bahan baku yang telah dipesan selama 7 hari (lead time) sebelumnya sudah tiba di gudang. Pada saat inilah persediaan yang tadinya sudah habis akan segera terisi lagi dengan bahan baku yang sudah diterima sesuai dengan jumlah pesanan hingga jumlah kuantitas persediaan optimal terpenuhi kembali. Ini berarti proses produksi tidak perlu terhenti karena kehabisan bahan baku namun dapat terus berjalan. Pada kenyataannya, jumlah pemakaian bahan baku setiap bulan tidaklah benar-benar konstan. Jumlah pemakaian bisa saja meningkat untuk memenuhi proses produksi, pada saat itulah dibutuhkan persediaan pengaman (safety stock). Persediaan pengaman merupakan persediaan tambahan yang diadakan untuk menjaga kelangsungan produksi dari kemungkinan terjadinya kekurangan bahan baku. Penentuan kuantitas persediaan pengaman perusahaan dapat dihasilkan dengan cara membagi antara standar deviasi yaitu 1.282 dibagi dengan jumlah waktu pemakaian selama 12 bulan, sehingga menghasilkan safety stock sebesar 107 pcs. Hal ini bisa terlihat pada tabel 6. dibawah ini. Dari hasil tabel XIV, dapat kita lihat bahwa jumlah safety stock

Tabel 6. Perhitungan Persediaan Pengaman (Safety Stock)

\begin{tabular}{|c|c|c|}
\hline $\begin{array}{c}\text { Standar deviasi } \\
\mathbf{a}\end{array}$ & $\begin{array}{c}\text { Jumlah Waktu } \\
\text { Pemakaian (bulan) } \\
\mathbf{b}\end{array}$ & $\begin{array}{c}\text { Safety Stock (pcs) } \\
\mathbf{c}=\mathbf{a} / \mathbf{b}\end{array}$ \\
\hline 1.282 & 12 & 107 \\
\hline
\end{tabular}

\section{Jarak Waktu Antar Pesanan}

Jarak waktu antar pesanan adalah selisih waktu saat pemesanan yang satudilakukan dengan pemesanan berikutnya. Dengan menghitung jarak waktu antar pesanan, kita dapat memperkirakan berapa lama persediaan bahan baku disimpan dalam gudang. Hal ini khususnya penting untuk mencegah terjadinya penurunan kualitas bahan baku akibat terlalu lama disimpan. Jarak waktu antar pesanan dihitung dengan mengalikan jumlah hari kerjadalam setahun kemudian membaginya dengan jumlah permintaan selama setahun. Dalam penelitian ini, diasumsikan bahwa jumlah hari dalam setahun adalah 360 hari. Hasil perhitungan jarak waktu antar pesanan dapat dilihat pada Tabel 7.

Tabel 7. Perhitungan Jarak Waktu Antar Pesanan

\begin{tabular}{|c|c|c|c|c|}
\hline Bahan Baku & $\begin{array}{c}\text { Jumlah hari } \\
\text { Kerja/tahun } \\
(\mathrm{W})\end{array}$ & $\begin{array}{c}\text { Kualitas } \\
\text { pesanan } \\
\text { optimal }\left(\mathrm{Q}^{*}\right)\end{array}$ & $\begin{array}{c}\text { Permintaan/ } \\
\text { tahun (D) }\end{array}$ & $\begin{array}{c}\text { Jarak Waktu } \\
\text { antar pesanan } \\
\text { (T=WQ*/D) }\end{array}$ \\
\hline cup $240 \mathrm{ml}$ & 360 & 170.955 & 1.754 .700 & 35 \\
\hline
\end{tabular}

Pada Tabel 7. ditunjukkan bahwa jarak antar waktu pesanan pada bahan baku cup 240 ml adalah 35 hari. Ini berarti bahan baku disimpan paling sedikit selama 35 hari di gudang, dikarenakan waktu simpan yang cukup singkat risiko penurunan kualitas bahan baku akibat disimpan terlalu lama cukup berpengaruh pada perusahaan.

Hasil penelitian menunjukkan bahwa perusahaan dapat melakukan penghematan dengan menentukan kombinasi jumlah kuantitas pemesanan bahan baku dan frekuensi pemesanan yang optimal. Oleh karena itu, hal ini memungkinkan perusahaan untuk dapat menggunakan dana ekstra yang dimiliki untuk berinvestasi dalam bidang lain, misalnya untuk meningkatkan produktifitas produksi. Hal ini cocok mengingat luas gudang yang cukup luas untuk dapat menampung bahan baku dalam jumlah yang lebih banyak

\section{KESIMPULAN}

Diperoleh beberapakesimpulan sebagai berikut: Pembelian bahan baku cup $240 \mathrm{ml}$ untuk produksi AMDK yang optimal menurut metode EOQ (Economic Order Quantity) tahun 2013 pada PT. Curup Aquifers untuk setiap kali pesan sebesar 170.955 Pcs. Kuantitas persediaan pengaman (safety stock) menurut metode EOQ (Economic Order Quantity) tahun 2013 adalah 34.119 pcs, sedangkan dengan metode sederhana yang digunakan perusahaan persediaan pengaman tidak ada atau tidak diketahui. Dengan menggunakan metode EOQ (Economic Order Quantity) tahun 2013 pada PT. Curup Aquifers dapat dilakukan pemesanan sebanyak 10 kali dibandingkan yang digunakan perusahaan yaitu hanya sebanyak 9 kali. Biaya total persediaan untuk persediaan bahan baku cup $240 \mathrm{ml}$ (total cost) tahun 2013 pada PT. 
Curup Aquifers menggunakan metode EOQ (Economic Order Quantity) sebesar Rp. 56.185.495. Ini lebih kecil dibandingkan dengan biaya total yang dikeluarkan oleh perusahaan yaitu Rp. 132.939.944. Dengan menggunakan metode sederhana, PT. Curup Aquifers tidak menerapkan adanya titik pemesanan kembali (reorder point). Sedangkan dengan menggunakan metode EOQ, titik pemesanan kembali (reorder point) dilakukan pada saat mencapai jumlah 34.119 pcs. Penerapan metode EOQ pada perusahaan menghasilkan biaya yang lebih murah jika dibandingkan dengan metode yang selama ini diterapkan oleh perusahaan. Penghematan yang dihasilkan jika metode EOQ jika diterapkan pada perusahaan pada tahun 2013 sebesar Rp 76.754.449. Penelitian selanjutnya dapat menggunakan metode Decoupling dan Economic Lot Sizing serta menggunakan data time series

\section{DAFTAR PUSTAKA}

Assauri, Sofian, 2004 “Manajemen Produksi dan Operasi Edisi Revisi”,. Lembaga Penerbit FE-UI, Jakarta, Baroto T, 2002) Perencanaan dan Pengendalian Produksi, Ghalia. Indonesia, Jakarta.

Gunawan Adi Saputra dan Marwan Asri S.W, 1982. Anggaran Perusahaan, Edisi Ketiga, Jilid I. Yogyakarta, Penerbit BPFE.

Ginting, Rosnani. 2007. Sistem Produksi. Yogyakarta: Graha Ilmu.

Heizer, Jay, and Barry Render. 2001 Prinsip-prinsip Manajemen Operasi. Salemba Empat, Jakarta Heizer, Jay, and Barry Render. 2005 Manajemen. Operasi edisi 7, Buk-u 1 Penerbit Salemba Empat Hill Terry 2000. The Essence of Operations Management: Manajemen Operasi Yogyakarta: Andi Yogyakarta, Keputusan Menperindag, no. 167/1997 Tentang Air Minum Dalam Kemasan

Mulyadi. 1986. Akuntansi Biaya : Penentuan Harga Pokok Produk dan Pengendalian Biaya. Edisi 3. Yogyakarta: BPFE

Nasution, Arman \& Prasetyawan, Yudha. 2008. Perencanaan Dan Pengendalian Yogyakarta. Graha Ilmu,.

Peraturan Menteri Kesehatan Republik Indonesia Nomor 907/MENKES/SK/VII tahun 2002, tentang syarat-syarat dan pengawasan kualitas air.

Pujawan. I Nyoman. 2005. Supply Chain Management. Surabaya: Penerbit Guna. Widya

Rangkuti Freddy, 2007,Manajemen Persediaan,PT. Raja Grafindo Persada, Jakarta

Rangkuti Freddy, 1998. Business Plan: Teknik Membuat Perencanaan Bisnis Dan Analisis Kasus. Jakarta. Gramedia Pustaka Utama

Ristono Agus.2009. Manajemen Persediaan Edisi 1. Graham Ilmu: Yogyakarta.

Riyanto. Bambang, 2001. Dasar-Dasar Pembelanjaan Perusahaan, Edisi. Keempat, Cetakan Ketujuh, BPFE Yogyakarta

Schroeder. Roger G. 1993. Manajemen Operasional. Jakarta. Erlangga

Subagyo Pengestu, 2000, Manajemen Operasi, Edisi Pertama, Penerbit BPFE Yogyakarta

Supriyono. 2000. Sistem Pengendalian Manajemen. Jakarta: Erlangga

Sedarmayanti. 2009. Sumber Daya Manusia dan Produktivitas Kerja. Bandung: CV. Mandar Maju

Sugiyono. 2004. Metode Penelitian Bisnis. Alfabeta, CV. Bandung

Siagian Yolanda M.. 2007.Supply Chain Management dalam Dunia Bisnis. Jakarta. Grasindo

Tarnpubolon P Manahan,. 2004. Manajemen Operasional. Edisi Pertama. Ghalia. Indonesia, Jakarta

Yamit, Zulian. 2003. Manajemen Produksi dan Operasi. Second edition. Ekonosia. Fakultas Ekonomi UII, Yogyakarta. 